\title{
Politicians on Social Media. The online database of members of national parliaments on Twitter
}

\author{
Michael Haman; Milan Školník
}

Nota: Este artículo se puede leer en español en:

http://www.elprofesionaldelainformacion.com/contenidos/2021/mar/haman-skolnik_es.pdf

How to cite this article:

Haman, Michael; Školník, Milan (2021). "Politicians on Social Media. The online database of members of national parliaments on Twitter". Profesional de la información, v. 30, n. 2, e300217.

https://doi.org/10.3145/epi.2021.mar.17

Manuscript received on February $28^{\text {th }} 2021$ Accepted on March $25^{\text {th }} 2021$

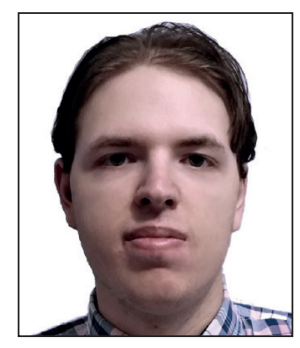

\author{
Michael Haman $\square$ \\ https://orcid.org/0000-0001-5772-2045 \\ University of Hradec Králové \\ Philosophical Faculty \\ Department of Political Science \\ Rokitanského, 62 \\ 50003 Hradec Králové, Czech Republic \\ michael.haman@uhk.cz
}

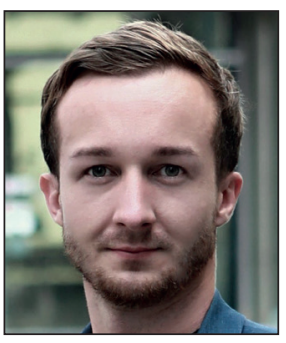

Milan Školník
https://orcid.org/0000-0002-0672-219X
University of Hradec Králové
Philosophical Faculty
Department of Political Science
Rokitanského, 62
50003 Hradec Králové, Czech Republic
milan.skolnik@uhk.cz

\begin{abstract}
In this article, we present the new online database Politicians on Social Media (https://www.politiciansonsocialmedia. com), which is intended for both academics and the public. This database was created with the aim of being continuously updated and providing relevant information on politicians' activity on social media. We first used data from this database to analyze Twitter. This social networking site is increasingly at the forefront of scientific interest due to its growing number of users. It is often examined with respect to how politicians use it. For politicians, Twitter is an opportunity not only to inform people about their activities but also to communicate directly with voters. Attention is focused on members of parliaments (MPs). We examine not only how many MPs have adopted Twitter but also how active they are on it. We also examine the determinants of Twitter adoption by MPs. We analyzed all countries of the European Union, the European Free Trade Association, and the United Kingdom. Therefore, the research includes 32 European countries. Our analysis revealed that most MPs have adopted Twitter in Western European countries such as France, Ireland, the Netherlands, Spain, or the United Kingdom, while MPs in Bulgaria, Hungary, Romania, and Slovakia use Twitter the least. Twitter is very actively used by Spanish and British MPs. By contrast, the least active MPs on Twitter are in post-communist countries such as Bulgaria and Romania. Our correlation analysis showed a strong association between the number of Twitter users in countries and the adoption of Twitter by MPs. Specifically, more Twitter users in a country correlates with its being adopted by more MPs.
\end{abstract}

\section{Keywords}

Twitter; Social media; Politicians; Legislators; Twitter adoption; Social media adoption; Members of parliaments; Parliaments; Political communication; Elections; Europe; Communication; Social networks.

\section{Funding}

This article is a result of the project of specific research Political Institutions and Political Behavior supported by the Philosophical Faculty of the University of Hradec Králové in 2021. 


\section{Introduction}

In this article, we present the brand-new online database Politicians on Social Media, which is intended for both academics and the public. This article describes the first output resulting from this database. We examine how many members of parliaments (MPs) have adopted Twitter and how active they are on it. We also examine the determinants of Twitter adoption by MPs. Our research includes 32 European countries.

\section{https://www.politiciansonsocialmedia.com}

Social media platforms are becoming increasingly important for political communication (Casero-Ripollés, 2018). For instance, in the last quarter of 2020, the so-

We present the brand new online database Politicians on Social Media

cial-networking company Twitter reported 192 million daily active users from around the world (Spangler, 2021). Politicians are aware of its importance, as it is a platform on which it is possible to address and communicate with voters.

In European countries, there are generally two forms of state establishments, namely parliamentary republics and constitutional monarchies. In both forms, either the unicameral parliament or the lower house of parliament, in cases with two chambers, has a key role to play. Based on the results of elections to such a legislature, a country's government is formed. The deputies are thus extremely important pieces on the imaginary political chessboard of the country.

In recent years in political science research, numerous databases have been created for analytical purposes. For political parties, there are Party Facts (Döring; Regel, 2019), ParlGov (Döring; Manow, 2020; Trechsel; Mair, 2011), the Chapel Hill Expert Survey (Polk et al., 2017), and the Global Party Survey, which can, for example, be used to measure populism (Norris, 2020). There are other databases on legislators within a single country, including legislators in the United States (Bonica, 2016; Inter-university Consortium for Political and Social Research; McKibbin, 1997), the British House of Commons (Eggers; Spirling, 2014), and the German Bundestag (Sieberer et al., 2020). There are also other ambitious projects that map the activity of politicians across time or space. The project Politicians on Wikipedia and DBpedia offers data covering a period of 15 years (Wagner, 2017). Parliamentary Careers in Comparison provides data from three European countries that date back to the beginning of World War II (Bailer et al., 2018). The Global Leadership Project is even more ambitious and covers almost 40,000 political profiles from 145 countries (Gerring et al., 2019). The most recent project is the Comparative Legislators Database, which includes various kinds of information, from socio-demographic to career information, on 45,000 politicians from the past and present from 10 countries (Göbel; Munzert, 2021). However, there is no comprehensive database that maps the activity of politicians on social media. Such a database would be very beneficial due to the ever-increasing influence of social media. Consequently, we created our own database on the adoption and use of social media by politicians.

The advantages of our database include its transparency and online availability. We further intend to make searching the database easy and intuitive. Databases are usually limited by the time period on which they focus. A lack of updates is generally one of the greatest weaknesses of databases of this type. Our intention is to continuously update the database and to provide it as a resource for both the public and researchers. However, its greatest advantage is its comprehensiveness, as politicians from all over the world will be gradually added. The database includes social media handles that will be regularly updated and contains politicians' identifiers including their parties and corresponding Party Facts IDs, making further cross-national analysis very easy.

However, our project and this article are not the first attempts to classify European members of parliaments on Twitter, as there currently is the Twitter Parliamentarian Database (TPD; Van-Vliet; Törnberg; Uitermark, 2020). However, the TPD consists of politicians' tweets and other data from September 2017 to 31 October 2019. Since then, elections have been held in several countries, there have been changes in the composition of parliaments, and many MPs have newly adopted Twitter. Moreover, TPD only focuses on countries where over $45 \%$ of parliamentarians are on Twitter, whereas our main goal is to compare all countries to highlight differences between them. Therefore, this database does not suit our research purposes. We thus fill a gap in current research and offer a range of findings.

The article is divided into several parts. The theoretical part explains the importance of social media for politicians and provides an overview of the current state

\section{Politicians on Social Media} PoliticiansOnSocialMedia.con

Almost 5,000 politicians on Twitter from 32 European countries As of now, this website is in progress and offers only members of parliaments (lower chamber) on Twitter and basic information. In the following weeks, many features and detailed information on each politician will be added. In addition, politicians from other countries will be added.

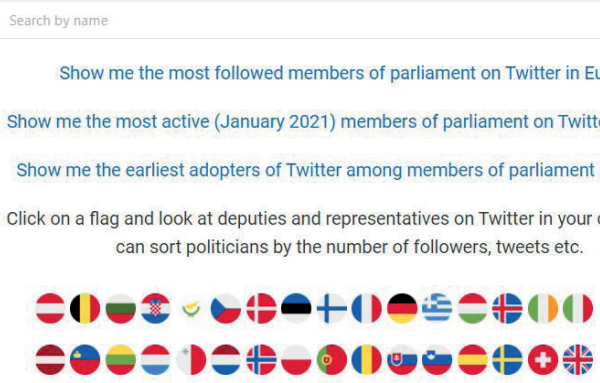

https://www.politiciansonsocialmedia.com 
of research in the field of social media adoption and use. The methodological part explains the analytical procedure. Two maps are offered in the analytical part. The first map reveals how many members of national parliaments in each European country have adopted Twitter. The second map shows how active MPs are on Twitter. Subsequently, the analysis shows the relationship between the number of Twitter users in a given country and the number of MPs who have adopted Twitter. The final part summarizes the findings and introduces other possible directions of research.

\section{Social media and politicians}

Social media can be useful sources of information on political issues. Thanks to their openness and interactivity, social media can contribute to the democratic control, transparency, and accountability of the political process and increase interest in public affairs (Bennett; Entman, 2010; Coleman; Blumler, 2009; Feenstra; Casero-Ripollés, 2014). They can moreover influence public opinion through fake news (Bennett; Livingston, 2018; Pierri; Artoni; Ceri, 2020). They can also influence the political process by setting a public agenda, as politicians and other social actors use these digital platforms to promote their affairs and seek to place them at the center of public debate (Casero-Ripollés, 2015). Social media are also tools that allow politicians to connect emotionally with users (voters) and present them a level of authenticity (Enli, 2015). However, above all, they remove barriers between politicians and voters and allow them to communicate directly.

\section{Social media adoptions by politicians}

There are several studies addressing the determinants of digital media adoption by politicians. Previous studies have focused mainly on websites (Vergeer; Hermans; Cunha, 2013), blogs (Carlson; Djupsund; Strandberg, 2014) or other digital channels, including social media, but did not distinguish between them (Chen; Smith, 2010). The scientific community also focused on examining the motives for adopting or using social media. An article examining these motives among Swiss politicians at the federal level revealed that politicians set up social media accounts primarily for self-promotion. Their second motive was to search for information. Their third motive was simply for fun, although this was not a strong motive (Hoffmann; Suphan; Meckel, 2016).

Some studies have only focused on Facebook. For example, there are two articles concerning the determinants of $\mathrm{Fa}$ cebook adoption by candidates for the US House of Representatives. The first article, which covered the 2006 and 2008 elections, demonstrated that it was Democrats better-funded candidates, and candidates in competitive higher-education constituencies who were more likely to adopt or use Facebook. Challengers and open-seat candidates were early adopters, but incumbents used Facebook more. Whether Facebook was used by other candidates in a constituency and whether a candidate had previously used digital technology were also important factors for Facebook adoption (Williams; Gulati, 2013). The conclusions of the second article, which mapped the 2012 elections, showed that there were no differences between Democratic and Re-

The MPs are extremely important pieces on the imaginary political chessboard of the country

publican candidates. Those who did not have Facebook were much more likely to be challengers or open-seat candidates. They were also more likely to be poorly funded, older, and running in a non-competitive constituency (Gulati; Williams, 2013). In the 2013 parliamentary elections in the Czech Republic, a party's role was important for the adoption of Facebook. Compared with traditional parties, candidates of one-man parties were less likely to adopt Facebook. Other important factors included whether a candidate used other digital channels. Candidates who did use them were more likely to use Facebook (Macková; Štětka, 2016).

Other studies have examined the two most common social media - Facebook and Twitter (Macková et al., 2017). Research into the use of these social media by Swedish and Norwegian lawmakers revealed that the adoption and use of Twitter and Facebook were more likely among younger politicians. Twitter was adopted more by challengers and, as with Facebook, by politicians without key positions. Creating a Twitter account was also more common among politicians from larger parties, and the same was true for Facebook (Larsson; Kalsnes, 2014). The decisive factor for the adoption of these two social media by German politicians was money -the more money candidates had in federal elections, the more likely they were to adopt Facebook and Twitter. An important determinant of adoption is also one's political party. Candidates from traditional parties such as the CDU/CSU and the SPD of Germany were more likely to have a Facebook account, while Pirates and Greens preferred Twitter, which was also adopted by more open candidates (Quinlan et al., 2018). There are also comprehensive studies that have examined the adoption of Twitter and Facebook by heads of state around the world. One of these studies found two determinants for the adoption of Twitter by world leaders. The first is the degree of democratization of the country -the greater the democracy, the more likely social media is adopted. The second determinant of adoption is social unrest in a country. Heads of state tend to respond to social unrest with narratives and thus establish a communication channel on social media (Barberá; Zeitzoff, 2018).

Social media can contribute to the transparency and accountability of the political process and increase interest in public affairs 


\section{The use of Twitter by politicians}

Many studies have examined what communication styles politicians have and what discursive strategies they choose (Golbeck; Grimes; Rogers, 2010; Dang-Xuan et al., 2013; Enli; Skogerb $\varnothing, 2013$; Karlsen; Enjolras, 2016; Bracciale; Martella, 2017; Alonso-Muñoz; Casero-Ripollés, 2018; Aguillón-Vale; Narváez-Serra, 2019; Masroor et al., 2019) and what are the interactions between politicians and the public on Twitter (Parmelee; Bichard, 2011; Tromble, 2018).

However, most academic attention addresses Twitter in the context of electoral campaigns (Vergeer, 2015; Jungherr, 2016; Segesten; Bossetta, 2017). The role of Twitter was examined in the 2009 Bundestag elections, (Plotkowiak; Stanoevska-Slabeva, 2013), the Dutch national elections in 2010 (Kruikemeier, 2014), and the Finnish parliamentary elections in 2011 (Strandberg, 2013). There are also studies regarding the Twitter accounts of the representatives of the parties running in the 2009 (Karlsen, 2011) and 2013 Norwegian elections (Larsson; Ihlen, 2015) and the presidential candidates in the first historically direct election of the president in the Czech Republic in 2013 (Štětka; Macková; Fialová, 2014). Twitter accounts of politicians were also analyzed during the 2014 Indian elections (Ahmed; Cho; Jaidka, 2017), the 2011 Canadian elections (Small, 2018), and both the 2016 (Pérez-Dasilva; Meso-Ayerdi; Mendiguren-Galdospín, 2018) and 2018 elections in Spain (Rivas-de-Roca; García-Gordillo; Bezunartea-Valencia, 2020). In Colombia, the role of Twitter in the mayoral elections in 2015 was examined (López-Londoño, 2018), and furthermore in the Colombian presidential elections held in 2018 (Ruano-López; Mosquera, 2018). Of course, academics did not forego studying the role of Twitter in the US presidential election of 2016 (Sainudiin et al., 2019), whose winner Donald Trump was known for frequent tweets. On this social network, he built the image of an apolitical superhero and used the platform to address voters (Schneiker, 2019; Kissas, 2020). However, the vast majority of studies focus on one election and one country. Therefore, studies comparing two or more countries or elections are beneficial. For example, an analysis of the use of Twitter in the 2010 British and Dutch elections found that Dutch candidates were twice as active as the British candidates and made more use of its interactive potential (Graham; Jackson; Broersma, 2016). From a methodological point of view, studies that combine several scientific techniques are also useful, an example of which is an article on the Twitter activity of the leaders of the main Spanish political parties in the 2015 election. With the help of quantitative, qualitative, and content analyses, the article revealed that emerging parties used Twitter for mobilization and general announcements, while traditional parties tweeted about specific policy proposals (López-García, 2016).

In addition to national elections, the use of Twitter was also monitored in elections for supranational bodies such as the European Parliament (Amaral et al., 2016; Daniel; Obholzer, 2020; Hrdina; Karaščáková, 2014; Meganck et al., 2019; Ramos-Serrano; Fernández-Gómez; Pineda, 2018; Rivas-de-Roca; García-Gordillo, 2021; Sandberg; Öhberg, 2017). One should note, however, that, in the 2009 European elections, Twitter was not yet widely used by candidates. It was used mainly by progressives, while conservatives were largely absent from it (Vergeer; Hermans; Sams, 2013). However, Twitter usage has changed over time. Research into the use of Twitter for political purposes primarily focuses on election campaigns, but there are also studies that investigate the use of Twitter in times of political crisis (Segado-Boj; Díaz-Campo; Lloves-Sobrado, 2015) and periods longer than one and a half years (Bracciale; Martella, 2017). Finally, there is also research on political elites' use of Twitter during the Covid-19 pandemic (Haman, 2020; Rufai; Bunce, 2020).

Two studies have addressed the issue of the determinants of Twitter use by members of the European Parliament (MEPs). First study concluded that they tweeted primarily during the weeks of parliamentary and committee meetings. High district magnitudes and preferential voting led to less frequent communication on Twitter. By contrast, a larger a number of voters in a constituency and the general prevalence of social media in a given country both correlated with more MEPs active on Twitter. Younger MEPs or their political parties were also more likely to be active on Twitter. Of course, MEPs are also active on Twitter during election campaigns in their countries. As far as ideology is concerned, Greens tweet the most, while the far right and Eurosceptics use Twitter the least (Daniel; Obholzer; Hurka, 2019). The second study revealed that MEPs' activity on Twitter is associated with age, as younger MEPs are more active on Twitter. Also, MEP's activity increases with the number of users that MEPs follow, and the percentage of the population using internet in a given country (Larsson, 2015). One may also mention studies that explicitly deal with the purposes for which politicians use Twitter. Study based on qualitative interviews with five French politicians showed that they used Twitter primarily to interact with voters, journalists, and other politicians, to disseminate information, and to monitor current events or public opinion (Frame; Brachotte, 2015). A quantitative study examining the Spanish Elections of 2016 concluded that politicians use Twitter primarily to disseminate policy proposals (López-Meri; Marcos-García; Casero-Ripollés, 2017). Other studies from Germany and New Zealand distinguish between two social media platforms and expand on previous findings. Politicians use Facebook for providing detailed communications, for mobilizing voters, and for making longer posts with pictures and videos. Politicians use Twitter to disseminate news, keep in touch with journalists, and to react quickly to current events (Ross; Bürger, 2014; Stier et al., 2018). Authors, who examined the Twitter usage of 97 United States senators over the 2009-2011 period, found that social media activity will likely increase among minority party members, underdogs, and extremists (Hong; Choi; Kim, 2019).

We determined Twitter as "adopted" by a politician when a MPs had an account and also used it in at least an elementary way 


\section{Methodology}

We used several techniques to collect data. First, we used Google search and the Google Knowledge Graph, which offers social profiles of known figures.

https://developers.google.com/knowledge-graph

However, these data are insufficient and not always correct. Google indexed parody accounts and non-active accounts. Moreover, for many politicians, Google does not show their profiles despite them having profiles. Therefore, we could not completely rely on Google data, and we had to verify each profile. Second, we used Twitter lists to find Twitter accounts. Some parliaments have official Twitter accounts, and they may also list their MPs on Twitter. However, some of these lists were missing MPs. Therefore, we also manually looked for MPs on Twitter. Generally, it was easy to identify MPs when their profile descriptions stated that they are indeed MPs. However, in some cases, MPs do not even use the description field, and in these cases, it was necessary to look more closely at the Twitter profiles. This issue was more problematic when there were several Twitter profiles with the same name. When this was the case, we examined the number of followers and image profiles. We also paid attention to whether the accounts could be fake or parody accounts. According to Twitter conditions and rules, parody and fake accounts should be stated as such, and we looked for other signs of fake and parody accounts and filtered them.

We used parliamentary websites to find lists of MPs. For Bulgaria, Cyprus, and Greece, we looked for names on Twitter using their writing system (Cyrillic or Greek) and also the Latin alphabet. We used the percentage of population on Twitter as our independent variable measuring the adoption of Twitter by MPs. These data were provided by DataReportal (Hootsuite; We Are Social, 2021), and we used the 2021 social media reports for each country (the 2020 report for Malta). The percentage of people in countries using Twitter is not officially known. Therefore, Hootsuite \& We Are Social compile several data sources to estimate the potential audience that marketers can reach using adverts on Twitter to the total population 13 years and older.

In order to collect data via Twitter API, we used programming language $R$ and its package $r$ Tweet (Kearney, 2019). We determined Twitter as "adopted" by a politician when a politician had an account and also used it in at least an elementary way. Members of parliaments who tweeted at least once between the beginning of January 2020 and the end of January 2021 were included in the analysis. Furthermore, Twitter accounts must have been public. When tweets were private, we excluded the account from the analysis. We also analyzed all MPs' Twitter activity in January 2021. We chose this month because it is the month coinciding most with the data collection period. Moreover, it would not be suitable to compare all MPs' Twitter accounts in 2020, as elections were held in several countries, and some MPs joined Twitter later in 2020.

We found that, for MPs who were active at least once in 2020 or in January 2021, the median of sent tweets in January 2021 was 32 . The first quartile was 7 , and the third quartile was 94 . The maximum value was 2,010 tweets, while some MPs did not send a single tweet. We therefore chose the value 32 to indicate a generally active presence, as this corresponds to more than one tweet per day and with the upper half of MPs. Therefore, the first analysis uses the number of MPs who sent at least one tweet in 2020 or January 2021, and the second analysis uses the MPs who sent at least 32 tweets in January 2021. We present results both in maps and tables in the following part.

\section{Analysis}

We visually present the results using two maps and descriptively present them in Table 1. Map 1 shows the adoption of Twitter by members of national parliaments in individual European countries. The map shows that, especially in Western European countries, almost every MP has an active account. More than $90 \%$ of MPs are on Twitter in Ireland, the United Kingdom, the Netherlands, France, and Spain. On the contrary, MPs from the states of the former Eastern bloc in particular are almost not present on Twitter. Less than $10 \%$ of MPs in Bulgaria, Romania, Hungary, and Slovakia have an active account. Moderate Twitter adoption is mainly seen in countries in central and northern Europe. Around $50 \%$ of MPs have an active Twitter account in the Czech Republic, Norway, and Sweden. However, the map does not show any prevailing trend in the adoption of Twitter by MPs. It cannot be unequivocally stated that Twitter is characteristic of Western European countries in comparison with Eastern European countries. There are exceptions. In the post-communist state of Poland, $80 \%$ of MPs are on Twitter, which is in line with Western democracies. In Portugal, by contrast, only $41 \%$ of MPs have adopted Twitter. This figure is draIn most examined European countries, more than $50 \%$ of MPs have adopted Twitter matically lower compared with its neighbor, Spain.

One noticeable trend is that a Twitter account is worthwhile for politicians to have. This point is demonstrated by the fact that, in most European countries, more than $50 \%$ of MPs have adopted Twitter. 


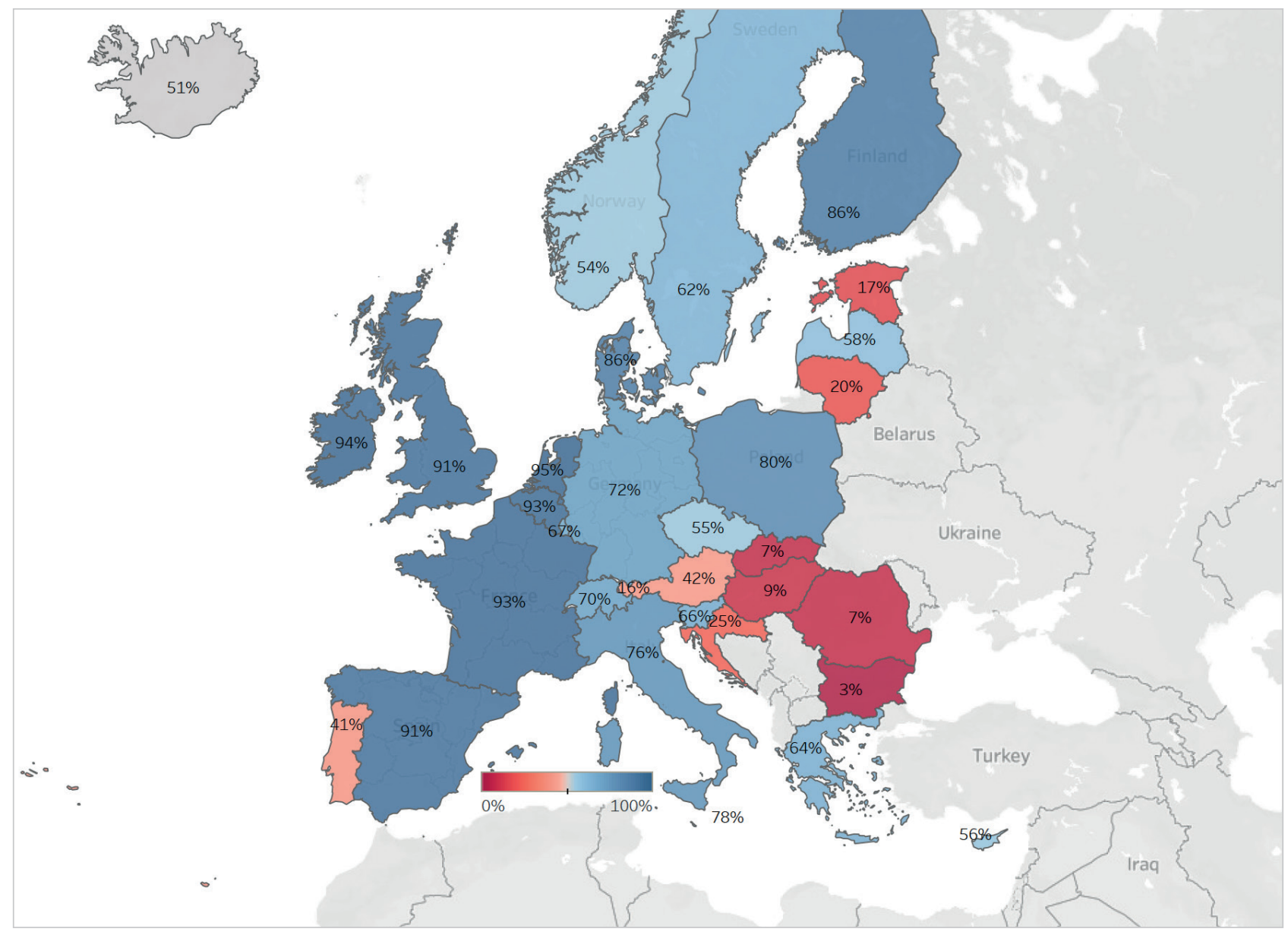

Map 1. National MPs on Twitter

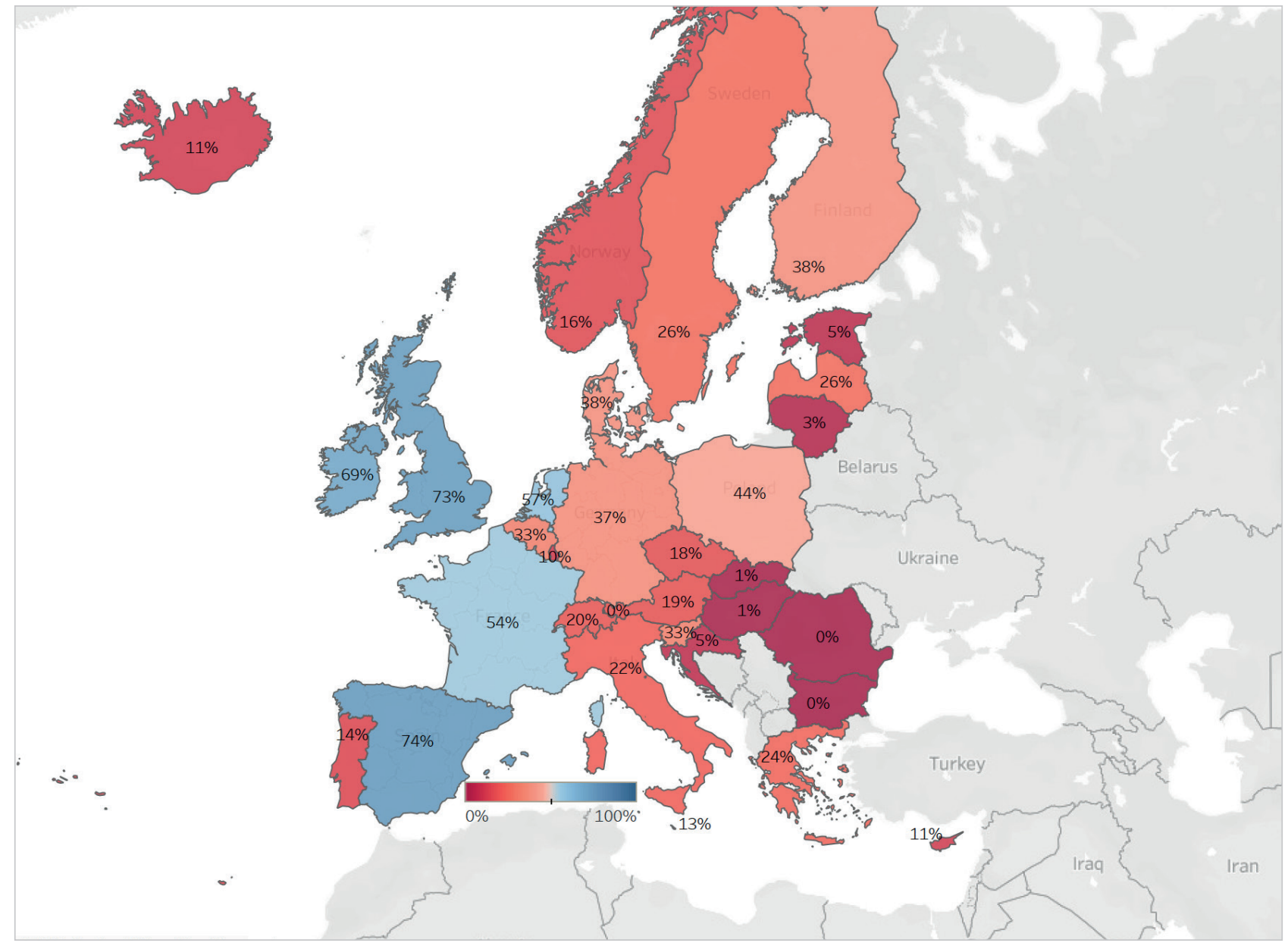

Map 2. National MPs who sent at least 32 tweets in January 2021 on Twitter 
Table 1. Countries and their MPs and population on Twitter

\begin{tabular}{|c|c|c|c|c|}
\hline Country & Number of MPs & $\begin{array}{c}\text { \% people on } \\
\text { Twitter }\end{array}$ & $\%$ MPs on Twitter & $\begin{array}{c}\% \text { MPs on Twitter } \\
\text { who sent at least } \\
\quad 32 \text { tweets }\end{array}$ \\
\hline Austria & 183 & 6.4 & 42.1 & 18.6 \\
\hline Belgium & 150 & 10.3 & 93.3 & 33.3 \\
\hline Bulgaria & 240 & 3.3 & 2.5 & 0.0 \\
\hline Croatia & 151 & 3.6 & 24.5 & 5.3 \\
\hline Cyprus $^{\mathrm{a}}$ & 54 & 9.6 & 55.6 & 11.1 \\
\hline Czech Republic & 200 & 6.1 & 54.5 & 17.5 \\
\hline Denmark $^{a}$ & 186 & 10.0 & 86.0 & 37.6 \\
\hline Estonia & 101 & 6.9 & 16.8 & 5.0 \\
\hline Finland & 200 & 11.7 & 86.0 & 38.0 \\
\hline France $^{\mathrm{a}}$ & 575 & 14.4 & 93.0 & 54.4 \\
\hline Germany & 709 & 7.9 & 71.5 & 36.8 \\
\hline Greece & 300 & 5.6 & 64.0 & 24.0 \\
\hline Hungary & 199 & 3.3 & 9.0 & 0.5 \\
\hline Iceland & 63 & 21.7 & 50.8 & 11.1 \\
\hline Ireland & 160 & 26.9 & 94.4 & 68.8 \\
\hline Italya & 629 & 5.2 & 75.7 & 22.1 \\
\hline Latvia & 100 & 6.4 & 58.0 & 26.0 \\
\hline Liechtenstein & 25 & 9.5 & 16.0 & 0.0 \\
\hline Lithuania & 141 & 4.9 & 19.9 & 2.8 \\
\hline Luxembourg & 60 & 25.1 & 66.7 & 10.0 \\
\hline Malta & 67 & 26.0 & 77.6 & 13.4 \\
\hline Netherlands ${ }^{\mathrm{a}}$ & 149 & 21.2 & 95.3 & 57.0 \\
\hline Norway & 169 & 13.9 & 54.4 & 16.0 \\
\hline Poland ${ }^{a}$ & 459 & 4.1 & 79.5 & 44.0 \\
\hline Portugal & 230 & 12.1 & 41.3 & 14.3 \\
\hline Romania $^{a}$ & 329 & 4.0 & 7.0 & 0.0 \\
\hline Slovakia & 150 & 3.0 & 6.7 & 0.7 \\
\hline Slovenia & 90 & 5.5 & 65.6 & 33.3 \\
\hline Spain & 350 & 18.3 & 91.1 & 74.3 \\
\hline Sweden & 349 & 13.4 & 61.9 & 26.4 \\
\hline Switzerland & 200 & 9.9 & 69.5 & 19.5 \\
\hline United Kingdom & 650 & 28.6 & 91.4 & 72.8 \\
\hline
\end{tabular}

Map 2 shows very active MPs' Twitter usage in individual European countries. More than 70\% of Spanish and British MPs sent more than 31 tweets in January 2021. Spain and the United Kingdom are thus countries in which not only almost every MP has Twitter but also countries with the most active legislators on Twitter. Similarly, Ireland, the Netherlands, and France are very active, with more than $50 \%$ of MPs being very active on Twitter. However, it cannot be stated that only the states of Western Europe are very active on Twitter, as demonstrated by Polish MPs, of which more than $40 \%$ are very active on Twitter. Nordic and Central European countries such as Finland, Denmark, and Germany, where almost $40 \%$ of MPs send more than 31 tweets a month. On the contrary, countries where MPs did not tweet include post-communist countries Bulgaria and Romania and the small Western monarchies of Luxembourg and Liechtenstein, and this corresponds to the fact that, in these countries, only a few MPs have adopted Twitter.

From Map 2 alone, certain trends are evident. First, MPs in countries where they have largely adopted Twitter are very active. These countries are mainly but not exclusively Western democracies. Conversely, in countries where few MPs have adopted Twitter, the MPs are also less active on the platform. In general, it can be said that MPs are very active on Twitter, as demonstrated by how, in many countries, more than half of MPs sent more than 31 tweets a month. 
Our ambition is not only to offer descriptive maps or tables but also to find what explains why Twitter is adopted by more MPs in some countries and less in others. Our assumption is that the more Twitter is used in a country, the more likely it is that MPs will adopt it to reach voters. The correlation shows that more users on Twitter correlates with more MPs on the platform. The Pearson correlation coefficient is 0.58 . This finding corresponds with the use of Twitter by the members of the European parliament, where it is also true that greater use of social media in a given country correlates with more frequent tweeting by MEPs (Daniel; Obholzer; Hurka, 2019). The number of Twitter users in a country is a variable that significantly predicts the adoption of Twitter by MPs.

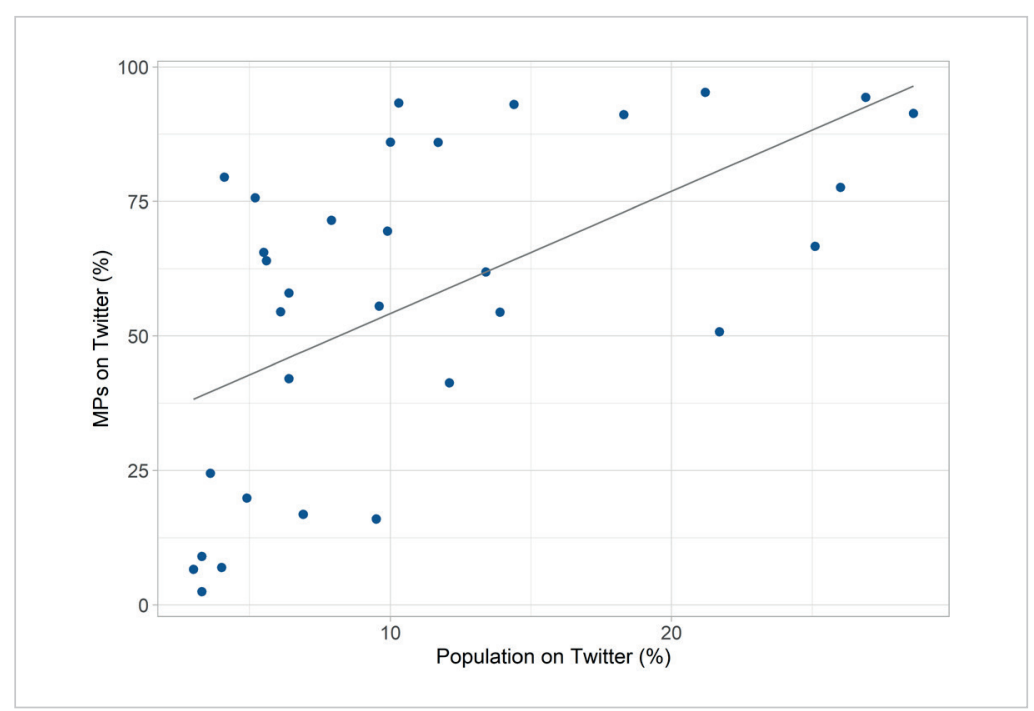

Graph 1. Correlation between the number of Twitter users in a given country and the number of MPs who have adopted it

These results can be explained by rational choice theory. Politicians calculate whether it makes sense to be on Twitter based on a cost-utility ratio. Some authors consider that costs for using social media are relatively low or even essentiaIly zero, for example during election campaigns (Lassen; Brown, 2011; Obholzer; Daniel, 2016). However, other studies have found a relationship between spending and adopting social media (Gulati; Williams, 2013; Quinlan et al., 2018; Williams; Gulati, 2013). In any case, the costs of Twitter for MPs undoubtedly include the time spent writing tweets and communicating with voters, journalists, and other actors. If they do not manage Twitter account themselves, they have to invest in the people or companies that manage it. Although MPs can put their assistants in charge of their social media accounts (Sabag-Ben-Porat; Lev-On; Lehman-Wilzig, 2020), these assistants' time is also costly, and MPs are fully responsible for the content of their tweets. Poorly formulated tweets can stir up significant media coverage and harm a politician's image. It is therefore in MPs' interest to at least control what assistants post, which is also time consuming.

Among the main uses of Twitter, it is possible to consider reaching out to voters and gaining new supporters with whom it is possible to maintain contact and to mobilize them during elections. It is also possible to inform followers about everyday activities and to respond quickly and directly to political events and opponents (Frame; Brachotte, 2015; López-Meri et al., 2017; Ross; Bürger, 2014; Stier et al., 2018), and therefore penetrate into the media space and set the agenda (Casero-Ripollés, 2015). However, if the costs are greater than utility, it is not rational to adopt Twitter. In countries where Twitter is not prevalent, it may not be an effective time or financial investment because it would be likely that the costs would exceed utility.

\section{Conclusions}

We examined the adoption and use of Twitter by MPs in European countries with the data from new database Politicians on Social Media. The analysis revealed that almost all MPs in Western Europe have an active Twitter account. Conversely, in post-communist countries, MPs are less interested in Twitter and are likely to use other media for communication. However, these conclusions cannot be generalized too much, as exceptions can be found both in the West (Portugal and small monarchies) and in the East (Poland). However, it can be stated that Twitter is generally a platform on which the majority of members of national parliaments in most European countries are present.

The analysis also showed that when there is widespread adoption of Twitter by MPs, it is more likely that these MPs will also be active on it. Once again, it turned out that the deputies who frequently tweeted were, in most cases, from Western European countries. In most post-communist countries, Twitter activity by MPs is very low.

We also found that the adoption rate of Twitter by politicians is strongly correlated with the overall percentage of Twitter users in a given country. In particular, the greater the percentage of Twitter users in a state, the more likely it is that MPs also adopt it. We have thus contributed to the debate over the determinants of social media adoption by politicians (Chen; Smith, 2010; Gulati; Williams, 2013; Williams; Gulati, 2013; Larsson; Kalsnes, 2014; Hoffmann; Suphan; Meckel, 2016; Macková; Štětka, 2016; Macková et al., 2017; Quinlan et al., 2018).

Our research has certain limits, both methodological and analytical. Methodological limits include the challenge of identifying politicians' Twitter accounts. Only a few national parliaments provide accurate and complete lists of their 
MPs on their Twitter profiles. Therefore, it was necessary to trace them. Thus, we cannot guarantee that all MPs' Twitter accounts were found, as MPs could in theory use different names. For example, they may only use their nicknames, which makes finding their accounts very difficult when their accounts are not listed somewhere. However, MPs should try to reach the largest audience possible, and therefore, this behavior would not make much sense. All methodological challenges were approached with the utmost care.

Among the analytical limits are that we only offered an overview of the adoption and use of Twitter and only examined one variable that could affect adoption (general use of Twitter in a country). We did not take into account other variables such as financing, ideology, or positions in parliaments, government, or party, as well as age, gender, and the use of other social media. There is room for further research, and a growing database that includes data on many of these variables should help researchers with such research.

Further research could also seek to explain the differences in the use of Twitter by MPs across countries. The significant differences in the adoption of Twitter are especially striking in neighboring countries that have a similar historical development or language, such as the Czech Republic and Slovakia or Spain and Portugal. Further research may also focus on the adoption and use of social media by members of government who, due to the nature of political systems in Europe, have a significant influence on everyday politics. In times of emergency, it is the government and its members who take the necessary measures, and social media are also means of rapid crisis communication with the public. It is also possible to monitor the adoption and use of Twitter by members of the second chambers of parliament, where they exist. Especially in asymmetric bicameralisms, where members of the upper chambers are not as important as members of the lower chambers, social media can potentially increase their importance.

Politicians are aware that, thanks to social media, they can quickly and purposefully reach the masses of voters. The database and subsequent research on the use of social media by politicians can thus contribute to the transparency and control of political communication between elected representatives and citizens, which is important for democracy.

\section{References}

Aguillón-Vale; Pedro-David; Narváez-Serra, Jellicy (2019). “Comportamiento del lenguaje de líderes políticos venezolanos en el uso de Twitter". Signo y pensamiento, v. 38, n. 74.

https://doi.org/10.11144/Javeriana.syp38-74.cllp

Ahmed, Saifuddin; Cho, Jaeho; Jaidka, Kokil (2017). "Leveling the playing field: The use of Twitter by politicians during the 2014 Indian general election campaign". Telematics and informatics, v. 34, n. 7, pp. 1377-1386.

https://doi.org/10.1016/j.tele.2017.09.005

Alonso-Muñoz, Laura; Casero-Ripollés, Andreu (2018). "Communication of European populist leaders on Twitter: Agenda setting and the 'more is less' effect". El profesional de la información, v. 27, n. 6, pp. 1193-1202.

https://doi.org/10.3145/epi.2018.nov.03

Amaral, Inês; Zamora, Rocío; Grandío, María del Mar; Noguera, José Manuel (2016). "Flows of communication and 'influentials' in Twitter: A comparative approach between Portugal and Spain during 2014 European elections". Observatorio $\left(O B S^{*}\right)$, v. 10, n. 2, pp. 111-128.

https://doi.org/10.15847/obsOBS1022016900

Bailer, Stefanie; Manow, Philip; Hug, Simon;Turner-Zwinkels, Tomas; Goet, Niels; Huwyler, Oliver; French, Elena (2018). Parliamentary careers in comparison.

https://parliamentarycareersincomparison.org

Barberá, Pablo; Zeitzoff, Thomas (2018). "The new public address system: Why do world leaders adopt social media?" International studies quarterly, v. 62, n. 1, pp. 121-130.

https://doi.org/10.1093/isq/sqx047

Bennett, W. Lance; Entman, Robert M. (eds.). (2010). Mediated politics: Communication in the future of democracy. Cambridge: Cambridge University Press. ISBN: 9780521783569

Bennett, W. Lance; Livingston, Steven (2018). "The disinformation order: Disruptive communication and the decline of democratic institutions". European journal of communication, v. 33 n. 2, pp. 122-139.

https://doi.org/10.1177/0267323118760317

Bonica, Adam (2016). "A data-driven voter guide for U.S. elections: Adapting quantitative measures of the preferences and priorities of political elites to help voters learn about candidates". RSF: The Russell Sage Foundation Journal of the social sciences, v. 2, n. 7, pp. 11-32.

https://doi.org/10.7758/rsf.2016.2.7.02 
Bracciale, Roberta; Martella, Antonio (2017). "Define the populist political communication style: the case of Italian political leaders on Twitter". Information, communication \& society, v. 20, n. 9, pp. 1310-1329.

https://doi.org/10.1080/1369118X.2017.1328522

Carlson, Tom; Djupsund, Göran; Strandberg, Kim (2014). "Taking risks in social media campaigning: The early adoption of blogging by candidates". Scandinavian political studies, v. 37, n. 1, pp. 21-40.

https://doi.org/10.1111/1467-9477.12011

Casero-Ripollés, Andreu (2015). “Estrategias y prácticas comunicativas del activismo político en las redes sociales en España”. Historia y comunicación social, v. 20, n. 2, pp. 533-548.

https://doi.org/10.5209/rev_HICS.2015.v20.n2.51399

Casero-Ripollés, Andreu (2018). "Research on political information and social media: Key points and challenges for the future". El profesional de la información, v. 27, n. 5, pp. 964-974.

https://doi.org/10.3145/epi.2018.sep.01

Chen, Peter John; Smith, Peter Jay (2010). "Adoption and use of digital media in election campaigns: Australia, Canada and New Zealand compared". Public communication review, v. 1, n. 1, pp. 3-26.

https://doi.org/10.5130/pcr.v1i1.1249

Coleman, Stephen; Blumler, Jay G. (2009). The internet and democratic citizenship: Theory, practice and policy. Cambridge: Cambridge University Press. ISBN: 9780511818271

https://doi.org/10.1017/CBO9780511818271

Dang-Xuan, Linh; Stieglitz, Stefan; Wladarsch, Jennifer; Neuberger, Christoph (2013). "An investigation of influentials and the role of sentiment in political communication on Twitter during election periods". Information, communication \& society, v. 16, n. 5, pp. 795-825.

https://doi.org/10.1080/1369118X.2013.783608

Daniel, William T.; Obholzer, Lukas (2020). "Reaching out to the voter? Campaigning on Twitter during the 2019 European elections". Research \& politics, v. 7, n. 2. https://doi.org/10.1177/2053168020917256

Daniel, William T.; Obholzer, Lukas; Hurka, Steffen (2019). "Static and dynamic incentives for Twitter usage in the European Parliament". Party politics, v. 25, n. 6, pp. 771-781.

https://doi.org/10.1177/1354068817747755

Döring, Holge; Manow, Philip (2020). ParlGov. Parliaments and governments database: Information on parties, elections and cabinets in modern democracies.

http://www.parlgov.org

Döring, Holger; Regel, Sven (2019). "Party Facts: A database of political parties worldwide”. Party politics, v. 25, n. 2, pp. 97-109.

https://doi.org/10.1177/1354068818820671

Eggers, Andrew C.; Spirling, Arthur (2014). “Electoral security as a determinant of legislator activity, 1832-1918: New data and methods for analyzing British political development". Legislative studies quarterly, v. 39, n. 4, pp. 593-620.

https://doi.org/10.1111/lsq.12059

Enli, Gunn-Sara (2015). “Mediated authenticity: How the media constructs reality”. New York: Peter Lang. ISBN: 9781 433114854

Enli, Gunn-Sara; Skogerbø, Eli (2013). "Personalized campaigns in party-centred politics". Information, communication \& society, v. 16, n. 5, pp. 757-774.

https://doi.org/10.1080/1369118X.2013.782330

Feenstra, Ramón A.; Casero-Ripollés, Andreu (2014). "Democracy in the digital communication environment: A typology proposal of political monitoring processes". International journal of communication, v. 8, n. 1, pp. 2448-2468.

https://doi.org/ 10.4185/rlcs-2017-1223en

Frame, Alex; Brachotte, Gilles (2015). "Le tweet stratégique: Use of Twitter as a PR tool by French politicians". Public relations review, v. 41, pp. 2, 278-287.

https://doi.org/10.1016/j.pubrev.2014.11.005

Gerring, John; Oncel, Erzen; Morrison, Kevin; Pemstein, Daniel (2019). "Who rules the world? A portrait of the global leadership class". Perspectives on politics, v. 17, n. 4, pp. 1079-1097.

https://doi.org/10.1017/S1537592719000744 
Göbel, Sascha; Munzert, Simon (2021). "The comparative legislators database". British Journal of political science. https://doi.org/10.1017/S0007123420000897

Golbeck, Jennifer; Grimes, Justin M.; Rogers, Anthony (2010). "Twitter use by the U.S. Congress". Journal of the American Society for Information Science and Technology, v. 61, n. 8, pp. 1612-1621.

https://doi.org/10.1002/asi.21344

Graham, Todd; Jackson, Dan; Broersma, Marcel (2016). "New platform, old habits? Candidates' use of Twitter during the 2010 British and Dutch general election campaigns". New media \& society, v. 18, n. 5, pp. 765-783.

https://doi.org/10.1177/1461444814546728

Gulati, Girish J.; Williams, Christine B. (2013). "Social media and campaign 2012: Developments and trends for Facebook adoption". Social science computer review, v. 31, n. 5, pp. 577-588.

https://doi.org/10.1177/0894439313489258

Haman, Michael (2020). "The use of Twitter by state leaders and its impact on the public during the Covid-19 pandemic". Heliyon, v. 6, n. 11, e05540.

https://doi.org/10.1016/j.heliyon.2020.e05540

Hoffmann, Christian Pieter; Suphan, Anne; Meckel, Miriam (2016). “The impact of use motives on politicians' social media adoption". Journal of information technology \& politics, v. 13, n. 3, pp. 239-256.

https://doi.org/10.1080/19331681.2016.1169241

Hong, Sounman; Choi, Haneul; Kim, Taek Kyu (2019). "Why do politicians tweet? Extremists, underdogs, and opposing parties as political tweeters". Policy \& internet, v. 11, n. 3, pp. 305-323.

https://doi.org/10.1002/poi3.201

Hootsuite; We Are Social (2021). Digital 2021 Global digital overview.

https://datareportal.com/reports/digital-2019-global-digital-overview

Hrdina, Matouš; Karaščáková, Zuzana (2014). “Parties, pirates and politicians: The 2014 European Parliamentary elections on Czech Twitter". Human affairs, v. 24, n. 4, pp. 437-451.

https://doi.org/10.2478/s13374-014-0239-4

Inter-university Consortium for Political and Social Research; McKibbin, Carroll (1997). Roster of United States congressional officeholders and biographical characteristics of members of the United States Congress, 1789-1996.

Jungherr, Andreas (2016). "Twitter use in election campaigns: A systematic literature review". Journal of information technology \& politics, v. 13, n. 1, pp. 72-91.

https://doi.org/10.1080/19331681.2015.1132401

Karlsen, Rune (2011). "A platform for individualized campaigning? Social media and parliamentary candidates in the 2009 Norwegian election campaign". Policy \& internet, v. 3, n. 4, pp. 1-25.

https://doi.org/10.2202/1944-2866.1137

Karlsen, Rune; Enjolras, Bernard (2016). "Styles of social media campaigning and influence in a hybrid political communication system: Linking candidate survey data with Twitter data". International journal of press/politics, v. 21, n. 3, pp. 338-357.

https://doi.org/10.1177/1940161216645335

Kearney, Michael (2019). "rtweet: Collecting and analyzing Twitter data". Journal of open source software, v. 4, n. 42, 1829.

https://doi.org/10.21105/joss.01829

Kissas, Angelos (2020). "Performative and ideological populism: The case of charismatic leaders on Twitter". Discourse \& society, v. 31, n. 3, pp. 268-284.

https://doi.org/10.1177/0957926519889127

Kruikemeier, Sanne (2014). "How political candidates use Twitter and the impact on votes". Computers in human behavior, v. 34, pp. 131-139.

https://doi.org/10.1016/j.chb.2014.01.025

Larsson, Anders-Olof (2015). "The EU Parliament on Twitter - Assessing the permanent online practices of parliamentarians". Journal of information technology and politics, v. 12, n. 2, pp. 149-166.

https://doi.org/10.1080/19331681.2014.994158

Larsson, Anders-Olof; Ihlen, Øyvind (2015). "Birds of a feather flock together? Party leaders on Twitter during the 2013 Norwegian elections". European journal of communication, v. 30, n. 6, pp. 666-681.

https://doi.org/10.1177/0267323115595525 
Larsson, Anders-Olof; Kalsnes, Bente (2014). “'Of course we are on Facebook': Use and non-use of social media among Swedish and Norwegian politicians". European journal of communication, v. 29, n. 6, pp. 653-667.

https://doi.org/10.1177/0267323114531383

Lassen, David S.; Brown, Adam R. (2011). "Twitter: The electoral connection?". Social science computer review, v. 29, n. 4, pp. 419-436. https://doi.org/10.1177/0894439310382749

López-García, Guillermo (2016). “'”New' vs 'old' leaderships: the campaign of Spanish general elections 2015 on Twitter”. Communication \& society, v. 29, n. 3, pp. 149-168.

https://doi.org/10.15581/003.29.3.149-168

López-Londoño, Luis-Miguel (2018). "La campaña a la Alcaldía de Manizales (Colombia) en Twitter: un caso para comprender la influencia de los medios en la interacción online entre candidatos y ciudadanos". Palabra clave. Revista de comunicación, v. 21, n. 3, pp. 798-830.

https://doi.org/10.5294/pacla.2018.21.3.7

López-Meri, Amparo; Marcos-García, Silvia; Casero-Ripollés, Andreu (2017). "What do politicians do on Twitter? Functions and communication strategies in the Spanish electoral campaign of 2016". El profesional de la información, v. 26, n. 5, pp. 795-804. https://doi.org/10.3145/epi.2017.sep.02

Macková, Alena; Štětka, Václav (2016). "Walking the party line? The determinants of Facebook's adoption and use by Czech parliamentarians". Medijske studije, v. 7, n. 14, pp. 157-175.

https://doi.org/10.20901/ms.7.14.11

Macková, Alena; Štetka, Václav; Zápotocký, Jan; Hladík, Radim (2017). "Who is afraid of the platforms? Adoption of and strategies for use of social media by politicians in the Czech Republic". In: Surowiec, Paweł; Štětka, Václav. Social media and politics in Central and Eastern Europe. London: Routledge, pp. 23-44. ISBN: 9781138100824

Masroor, Farzana; Khan, Qintarah N.; Aib, Iman; Ali, Zulfiqar (2019). "Polarization and ideological weaving in Twitter discourse of politicians". Social media + society, v. 5, n. 4.

https://doi.org/10.1177/2056305119891220

Meganck, Shana; Guidry, Jeanine; Messner, Marcus; Medina-Messner, Vivian (2019). “@JunckerEU vs. @MartinSchulz: How leading candidates in the 2014 European Parliament elections campaigned on Twitter". First Monday, v. 24 , n. 11. https://doi.org/10.5210/fm.v24i11.9856

Norris, Pippa (2020). “Measuring populism worldwide". Party politics, v. 26, n. 6, pp. 697-717. https://doi.org/10.1177/1354068820927686

Obholzer, Lukas; Daniel, William T. (2016). "An online electoral connection? How electoral systems condition representatives' social media use". European Union politics, v. 17, n. 3, pp. 387-407. https://doi.org/10.1177/1465116516630149

Parmelee, John H.; Bichard, Shannon L. (2011). Politics and the Twitter revolution: How tweets influence the relationship between political leaders and the public. Lanham: Lexington Books. ISBN: 9780739165003

Pérez Dasilva, Jesús; Meso Ayerdi, Koldobico; Mendiguren Galdospín, Terese (2018). “Do Spanish political leaders interact with the media and journalists via Twitter?" Communication and society, v. 31, n. 3, pp. 299-317.

https://doi.org/10.15581/003.31.3.299-317

Pierri, Francesco; Artoni, Alessandro; Ceri, Stefano (2020). "Investigating Italian disinformation spreading on Twitter in the context of 2019 European elections". PLoS one, v. 15, n. 1, e0227821.

https://doi.org/10.1371/journal.pone.0227821

Plotkowiak, Thomas; Stanoevska-Slabeva, Katarina (2013). "German politicians and their Twitter networks in the Bundestag election 2009". First Monday, v. 18, n. 5.

https://doi.org/10.5210/fm.v18i5.3816

Polk, Jonathan; Rovny, Jan; Bakker, Ryan; Edwards, Erica; Hooghe, Liesbet; Jolly, Seth; Koedam, Jelle; Kostelka, Filip; Marks, Gary; Schumacher, Gijs; Steenbergen, Marco; Vachudova, Milada; Zilovic, Marko (2017). "Explaining the salience of anti-elitism and reducing political corruption for political parties in Europe with the 2014 Chapel Hill Expert Survey data". Research \& politics, v. 4, n. 1, 205316801668691.

https://doi.org/10.1177/2053168016686915

Quinlan, Stephen; Gummer, Tobias; Roßmann, Joss; Wolf, Christof (2018). “'Show me the money and the party!' - variation in Facebook and Twitter adoption by politicians". Information, communication \& society, v. 21, n. 8, pp. $1031-1049$. https://doi.org/10.1080/1369118X.2017.1301521 
Ramos-Serrano, Marina; Fernández Gómez, Jorge David; Pineda, Antonio (2018). “'Follow the closing of the campaign on streaming': The use of Twitter by Spanish political parties during the 2014 European elections". New media \& society, v. 20 , n. 1 , pp. $122-140$.

https://doi.org/10.1177/1461444816660730

Rivas-de-Roca, Rubén; García-Gordillo, Mar (2021). "Thematic agenda on Twitter in the 2019 European Parliament elections: A comparative study between 'Spitzenkandidaten' and national candidates". Tripodos, n. 49, pp. 29-49. https://doi.org/10.51698/tripodos.2020.49p29-49

Rivas-de-Roca, Rubén; García-Gordillo, Mar; Bezunartea-Valencia, Ofa (2020). "The far-right's influence on Twitter during the 2018 Andalusian elections: an approach through political leaders". Communication \& society, v. 33, n. 2, pp. 227-242.

https://doi.org/10.15581/003.33.2.227-242

Ross, Karen; Bürger, Tobias (2014). "Face to face(book): Social media, political campaigning and the unbearable lightness of being there". Political science, v. 66, n. 1, pp. 46-62.

https://doi.org/10.1177/0032318714534106

Ruano, Luis-Eduardo; López, Juan-Camilo; Mosquera, Jonathan-Felipe (2018). "La política y lo político en Twitter: Análisis del discurso de los candidatos presidenciales de Colombia". Risti. Revista ibérica de sistemas e tecnologias de informação, v. 28, n. 28, pp. 57-71.

https://doi.org/10.17013/risti.28.57-71

Rufai, Sohaib R.; Bunce, Catey (2020). “World leaders' usage of Twitter in response to the Covid-19 pandemic: a content analysis". Journal of public health, v. 42, n. 3, pp. 510-516.

https://doi.org/10.1093/pubmed/fdaa049

Sabag-Ben-Porat, Chen; Lev-On, Azi; Lehman-Wilzig, Sam (2020). "Silent partners: How politicians' Facebook communication with constituents is mediated". Politics and policy, v. 48, n. 3, pp. 550-569.

https://doi.org/10.1111/polp.12352

Sainudiin, Raazesh; Yogeeswaran, Kumar; Nash, Kyle; Sahioun, Rania (2019). "Characterizing the Twitter network of prominent politicians and SPLC-defined hate groups in the 2016 US presidential election". Social network analysis and mining, v. 9, n. $1,34$.

https://doi.org/10.1007/s13278-019-0567-9

Sandberg, Linn A. C.; Öhberg, Patrik (2017). “The role of gender in online campaigning: Swedish candidates' motives and use of social media during the European election 2014". Journal of information technology \& politics, v. 14, n. 4, pp. $314-333$. https://doi.org/10.1080/19331681.2017.1369918

Schneiker, Andrea (2019). "Telling the story of the superhero and the anti-politician as president: Donald Trump's branding on Twitter". Political studies review, v. 17, n. 3, pp. 210-223.

https://doi.org/10.1177/1478929918807712

Segado-Boj, Francisco; Díaz-Campo, Jesús; Lloves-Sobrado, Beatriz (2015). “Líderes latinoamericanos en Twitter. Viejas costumbres para nuevos medios en tiempos de crisis políticas". Revista latina de comunicacion social, v. 70, n. 2, pp. 156-173.

https://doi.org/10.4185/RLCS-2015-1040

Segesten, Anamaria-Dutceac; Bossetta, Michael (2017). "A typology of political participation online: How citizens used Twitter to mobilize during the 2015 British general elections". Information, communication \& society, v. 20, n. 11, pp. 1625-1643.

https://doi.org/10.1080/1369118X.2016.1252413

Sieberer, Ulrich; Saalfeld, Thomas; Ohmura, Tamaki; Bergmann, Henning; Bailer, Stefanie (2020). "Roll-call votes in the German Bundestag: A new dataset, 1949-2013". British journal of political science, v. 50, n. 3, pp. 1137-1145. https://doi.org/10.1017/S0007123418000406

Small, Tamara A. (2018). “Online negativity in Canada”. Journal of language and politics, v. 17, n. 2, pp. 324-342. https://doi.org/10.1075/jlp.17008.sma

Štětka, Václav; Macková, Alena; Fialová, Marta (2014). “A winding road from "likes" to votes”. In: Pătruț, Bogdan; Pătruț, Monica. Social media in politics. Case studies on the political power of social media. Cham: Springer, pp. 225-244. ISBN: 9783319046662

https://doi.org/10.1007/978-3-319-04666-2_13 
Stier, Sebastian; Bleier, Arnim; Lietz, Haiko; Strohmaier, Markus (2018). "Election campaigning on social media: Politicians, audiences, and the mediation of political communication on Facebook and Twitter". Political communication, v. 35, n. 1, pp. 50-74.

https://doi.org/10.1080/10584609.2017.1334728

Strandberg, Kim (2013). "A social media revolution or just a case of history repeating itself? The use of social media in the 2011 Finnish parliamentary elections". New media \& society, v. 15, n. 8, pp. 1329-1347.

https://doi.org/10.1177/1461444812470612

Trechsel, Alexander H.; Mair, Peter (2011). "When parties (also) position themselves: An introduction to the EU profiler". Journal of information technology \& politics, v. 8, n. 1, pp. 1-20.

https://doi.org/10.1080/19331681.2011.533533

Tromble, Rebekah (2018). "The great leveler? Comparing citizen-politician Twitter engagement across three Western democracies". European political science, v. 17, n. 2, pp. 223-239.

https://doi.org/10.1057/s41304-016-0022-6

Van-Vliet, Livia; Törnberg, Petter; Uitermark, Justus (2020). “The Twitter parliamentarian database: Analyzing Twitter politics across 26 countries". PLoS one, v. 15, n. 9, e0237073.

https://doi.org/10.1371/journal.pone.0237073

Vergeer, Maurice (2015). "Twitter and political campaigning". Sociology compass, v. 9, pp. 745-760.

https://doi.org/10.1111/soc4.12294

Vergeer, Maurice; Hermans, Liesbeth; Cunha, Carlos (2013). "Web campaigning in the 2009 European Parliament elections: A cross-national comparative analysis". New media and society, v. 15, n. 1, pp. 128-148.

https://doi.org/10.1177/1461444812457337

Vergeer, Maurice; Hermans, Liesbeth; Sams, Steven (2013). “Online social networks and micro-blogging in political campaigning". Party politics, v. 19, n. 3, pp. 477-501.

https://doi.org/10.1177/1354068811407580

Wagner, Claudia (2017). "Politicians on Wikipedia and DBpedia (Version: 1.0.0)". Gesis - Leibniz-Institute for the Social Sciences.

https://doi.org/10.7802/1515

Williams, Christine B.; Gulati, Girish J. 'Jeff' (2013). "Social networks in political campaigns: Facebook and the congressional elections of 2006 and 2008". New media \& society, v. 15, n. 1, pp. 52-71.

https://doi.org/10.1177/1461444812457332

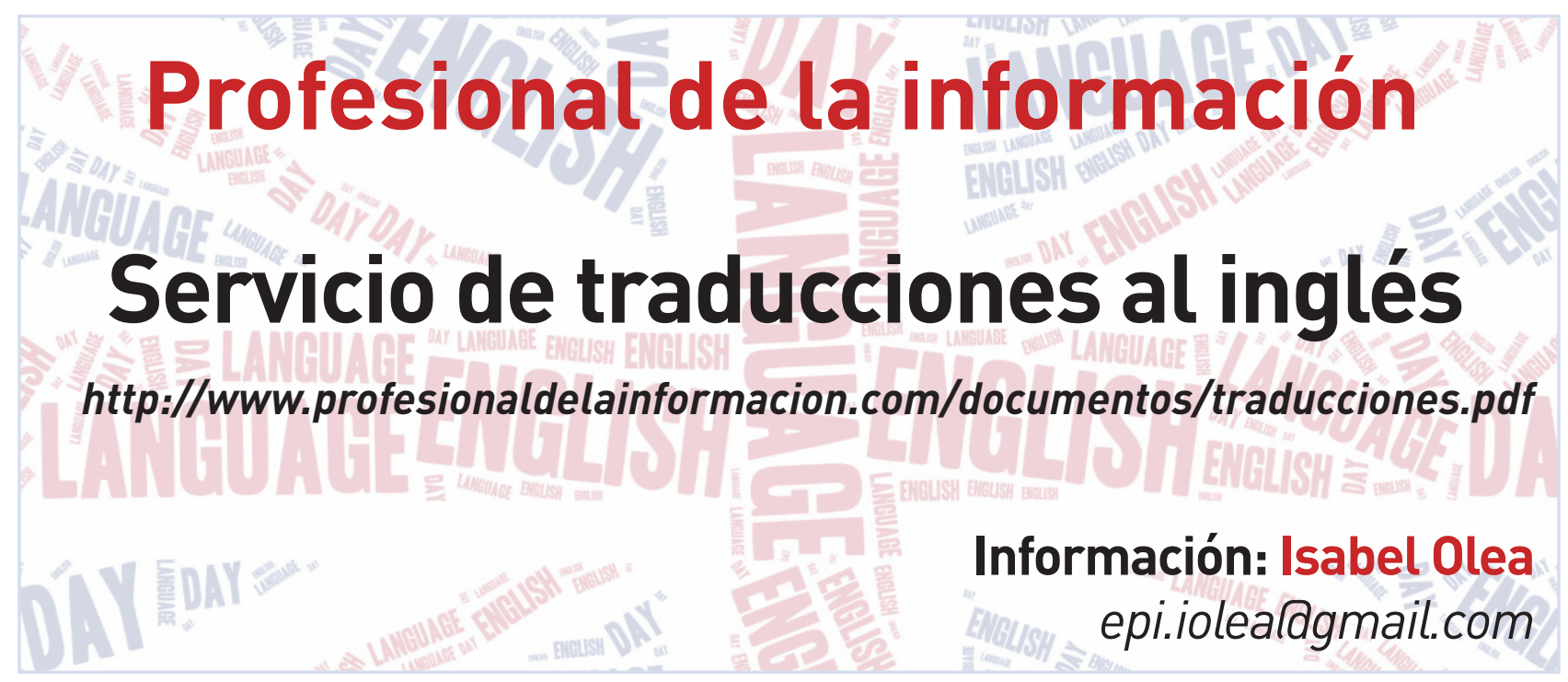

